\title{
POLITYKA INFORMACYJNA ADMINISTRACJI PUBLICZNEJ W SYTUACJACH KRYZYSOWYCH
}

Obecnie społeczeństwa wysoko rozwinięte domagają się bezpieczeństwa na najwyższym poziomie, często utożsamionym z pewną (stuprocentową) ochroną. Bez wahania można powiedzieć, że na początku XXI wieku także w nas zrodziła się potrzeba kompleksowego minimalizowania ryzyk, czyli żądanie poszukiwania potencjalnych zagrożeń w każdej dziedzinie życia w celu ich identyfikacji i likwidacji. Administracja publiczna ze względu na swoją istotę (służbę społeczeństwu ${ }^{1}$ ) musi zaspokajać te żądania, stąd systematyczne jej modyfikacje wydają się nieodzowne. Jednak rzeczywistość wielokrotnie doświadcza nas, że samo przekształcanie nie wystarcza, lecz potrzeba także merytorycznego wzmocnienia urzędników, szczególnie w nowych warunkach działania (otoczeniu prawnym i organizacyjnym). Zatem spełnienie społecznych oczekiwań wymaga nieustannego dostosowywania, również pod względem mentalnym, administracji publicznej do jakże zmiennej rzeczywistości, a to nakłada już konieczność przeprowadzania systematycznych szkoleń.

Jedno z nich, zatytułowane „Funkcjonowanie województwa wielkopolskiego w przypadku wystapienia pryszczycy podczas podnoszenia gotowości obronnej państwa", odbyło się w maju 2013 r. w Dolsku (powiat śremski). Organizatorzy, Wydziat Bezpieczeństwa i Zarzadzania Kryzysowego Wielkopolskiego Urzędu Wojewódzkiego w Poznaniu oraz Wielkopolski Wojewódzki Inspektorat Weterynarii, zaaranżowali hipotetyczną sytuację kryzysową, którą usunąć musieli powiatowi lekarze weterynarii wspólnie z urzędnikami starostw powiatowych. Warto podkreślić, że dzięki tej inicjatywie udało się przeszkolić ponad stu uczestników oraz, co ważniejsze, poznać kluczowe problemy przy współdziałaniu służb, inspekcji i straży z pozostałymi podmiotami administracji publicznej $\mathrm{w}$ nowych warunkach organizacyjnych i prawnych. Ustawa o zarzadzaniu kryzysowym z 26 kwietnia 2007 r. oraz Ustawa o wojewodzie i administracji rzqdowej $w$ województwie z 23 stycznia 2009 r. istotnie zmieniły specyfikę działania administracji publicznej w sytuacjach kryzysowych. Newralgiczną trudnością w tego typu zdarzeniach okazała się polityka informacyjna ${ }^{2}$, a dokładniej sposób

1 Wydaje się, że należy podtrzymać stanowisko o służebnej roli administracji publicznej, choć nadal tę normę traktuje się fasadowo. „Jednym z powodów deprecjacji służby jest pojmowanie związanych z nią nierówności głównie na sposób socjologiczny. Chcemy siebie widzieć raczej na wyższym niż niższym szczeblu drabiny społecznej” (Etos, 2009: 29).

2 Polityka informacyjna ma na celu ,ustalanie treści przekazu prasy, radia i telewizji poprzez dostarczanie właściwych informacji. Pierwotnym zamierzeniem tych działań jest wywieranie wpływu na media, przy czym po części zajmują się nimi profesjonalni pośrednicy, np. rzecznicy prasowi, agencje" (Schulz, 2006: 168). 
i zakres informowania społeczeństwa o podjętych działaniach antykryzysowych czy o bieżących decyzjach podejmowanych w zespołach zarządzania kryzysowego. Z jednej strony, przeciwstawiano się ograniczeniom w przypadku informowania osób trzecich, a z drugiej - wskazywano na istotne ryzyko wybuchu paniki po, często przypadkowo udzielonej, niefortunnej wypowiedzi ${ }^{3}$. Przede wszystkim przed rozstrzygnięciem tej kwestii należy znaleźć i scharakteryzować istotę problemu, a następnie sformułować dostosowawcze rekomendacje o kluczowym znaczeniu.

W nowym wieku ostatecznie staliśmy się społeczeństwem informacyjnym, czyli informacja przeistoczyła się w strategiczny zasób, często ważniejszy od dóbr materialnych, od którego pozostajemy coraz bardziej uzależnieni. Dla wielu osób zdobywanie, przetwarzanie, przesyłanie danych stało się podstawą życia zawodowego i prywatnego, a nawet pewnym sposobem życia. Upublicznianie informacji w serwisach społecznościowych dla niektórych nabrało takiego znaczenia, że zatracili poczucie prywatności, a nawet przedłożyli rzeczywistość wirtualną nad realną. Zatem radykalne podejście, charakterystyczne dla systemów totalitarnych, czyli brak lub znaczne ograniczanie atrakcyjnych komunikatów, w obecnych czasach wydaje się nietrafionym rozwiązaniem. Wszechobecny postęp technologiczny i techniczny uniemożliwia blokadę informacyjna, o czym świadczą przekazy z sytuacji kryzysowych w kilka minut po wydarzeniu. Wielokrotnie internet był doskonałym środkiem przekazu w tego typu przypadkach, a po nim dopiero radio, telewizja i prasa. Powszechna dostępność urządzeń rejestrujących w połączeniu z siecią internetową skutkuje w praktyce natychmiastowym rozpowszechnieniem się treści, szczególnie kiedy można dostarczyć ją praktycznie bezkosztowo do każdego rejonu świata. Obecny poziom globalizacji powoduje, że zastosowanie ograniczeń w przepływie informacji staje się nieefektywne i zawsze znajdzie się alternatywna droga komunikacji ${ }^{4}$. Co więcej, polskie prawo nadaje uprawnienia dziennikarzom do zbierania i przekazywania informacji, zwane ,,prawem do informacji”. Posiada ono fundamentalne znaczenie dla działalności dziennikarskiej, choć nie ma charakteru bezwzględnego (Dobosz, 2012: 16). Jednak rzeczywistość rozmija się z intencją ustawodawcy i ,nie sposób przy tym ustrzec się smutnej refleksji, że ich [prekursorów liberalnej wizji prasy] koncepcje są także dzisiaj traktowane wybiórczo, a z treści głoszonych poglądów wybiera się jedynie te, które odpowiadają przyjętym tezom, potwierdzają potrzebę pełnej niczym nieskrępowanej wolności prasy, a pomija zdania głoszące potrzebę odpowiedzialności i poglądy wskazujące na wielkie niebezpieczeństwo treści publicystycznych dla stabilności społeczeństwa (U podstaw, 2010: 55). W efekcie podmioty powiązane z sytuacją kryzysową muszą pozostać

${ }^{3}$ Problem polega głównie na użyciu takiego zestawu słów, który brzmi niewiarygodnie lub, co gorsza, pozwala na modyfikacje wypowiedzi w celu dopasowania jej do określonej z góry tezy.

4 Warto zauważyć $\mathrm{w}$ jak odmienny sposób opinia międzynarodowa pozyskiwała informacje o awarii elektrowni jądrowej w Czarnobylu i Fukuszimie. W drugim przypadku publikowano niepewne informacje (także krótkie amatorskie filmy z komentarzem), później oficjalnie je potwierdzano lub dementowano, by następnie problem przedstawić w tradycyjnych środkach masowego przekazu z co najmniej jednodniowym opóźnieniem. W tym miejscu nasuwa się interesujące pytanie: jaką politykę informacyjną zastosowaliby radzieccy przywódcy, gdyby obecny poziom rozwoju technologicznego przenieść właśnie do 1986 roku? Wtedy, bez serwisów internetowych (YouTube) czy serwisów społecznościowych (Twitter, Facebook), udało się jedynie o dwa dni opóźnić reakcję sąsiednich państw. 
w stałym kontakcie przynajmniej z przedstawicielami społeczeństwa (dziennikarzami), aby ograniczyć spekulacje, szczególnie te medialne. Jednak trzeba założyć z dużym prawdopodobieństwem, że mimo otwartej polityki informacyjnej upubliczniane treści, ze względu na specyfikę rynku medialnego nastawionego na zysk, często pozostaną niezgodne z rzeczywistością. W 2012 roku upowszechnił się problem zafałszowanej soli spożywczej i środki masowego przekazu bezrefleksyjnie wykorzystały okazję do przyciaggnięcia uwagi, co zwiększało ich zyski. Pomimo otwartej polityki informacyjnej prowadzonej przez Wielkopolskiego Państwowego Wojewódzkiego Inspektora Sanitarnego nie udało się zapobiec konfabulacjom czy świadomemu zmyślaniu. Ten przypadek potwierdził, że bezsilność wobec medialnych spekulacji wynika z obowiązku administracji publicznej do wydawania komunikatów na podstawie sprawdzonych informacji popartych rzetelną analizą, co wymaga czasu jakże deficytowego w sytuacji kryzysowej.

Po doświadczeniach z 2012 r. widać wyraźnie, że nasze społeczeństwo ze szczególnym uwzględnieniem sektora informacyjnego, który żyje ze zdobywania, przetwarzania i dostarczania informacji, nie znosi próżni. Komunikaty, ze względów czysto ekonomicznych (zysków), muszą być nadawane permanentnie, stąd przy braku treści oficjalnych trzeba sięgać po informacje niepotwierdzone, niepełne i często odbiegające od rzeczywistości. W konsekwencji należy odrzucić zasadność stanowiska, w którym zakłada się brak komunikatów ze strony podmiotów odpowiedzialnych za bezpieczeństwo, ponieważ zawsze prowadzi to do budzącej niepewność spekulacji. „Uświadomienie osobom zagrożonym rodzaju zagrożenia i sposobów ochrony przed nim, chroni ich przed poczuciem bezsilności i bezradności. Pozwala zatem zmniejszyć lęk, a nawet jeśli nie, to czyni go bardziej konkretnym. Taki stan jest psychologicznie dużo lepiej tolerowany niż poczucie bezsilności i lęku przed nieznanym. Łatwiej jest wówczas zachować psychologiczną równowagę i poczucie kontroli nad sytuacją" (Konieczny, Wawrzynowicz, Mydlarska, 2011: 39). Powstaje zatem pytanie: w jaki sposób informować społeczeństwo o aktualnych wydarzeniach w przypadku pojawienia się sytuacji kryzysowej?

Specyfika bezpieczeństwa wiąże się ze skomplikowanymi, wielowątkowymi i wielopoziomowymi zależnościami w obszarze bezpieczeństwa, który nieustannie podlega poszerzeniu i w praktyce zaczyna obejmować każdą dziedzinę życia. Trudności w tej problematyce wynikają przede wszystkim z subiektywizmu, np. przy próbie określenia poczucia bezpieczeństwa, oraz braku uniwersalnych i powszechnie akceptowanych teorii wpisujących się w spójny system pojęciowy. Właśnie ze względu na specyfikę bezpieczeństwa, warto odnieść się do kultury bezpieczeństwa i wykorzystać do usystematyzowania wywodu jej trzy komponenty (zasoby, organizację i mentalność). Pojęcie „kultura bezpieczeństwa” sprowadzane jest do „sposobu postrzegania wyzwań, szans i zagrożeń, sposobu myślenia o bezpieczeństwie oraz sposobu odczuwania jego braku, a także sposobu zapewnienia bezpieczeństwa” (Tożsamość, 2009: 44). „Podstawowymi barierami w zapewnieniu bezpieczeństwa publicznego i zarządzaniu kryzysowym są: brak wystarczającej liczby zasobów [zasoby] oraz brak lub zakłócenia w przepływie informacji [organizacja], czego efektem jest nieodpowiednie wykorzystanie możliwości i brak lub podjęcie niewłaściwych działań [mentalność]" (Sienkiewicz-Małyjurek, Krynojewski, 2010: 89). W konsekwencji pierwsza część artykułu 
odnosi się do sposobu wykorzystania zasobów, w tym przypadku rzecznika prasowego i jego biura oraz środków masowego przekazu, do informowania o nagłych i istotnych dla określonej społeczności wydarzeniach ${ }^{5}$. Druga część artykułu sprowadza się do prezentacji i analizy obiegu informacji ${ }^{6}$, a dokładniej do ukazania prawidłowych relacji między podmiotami zainteresowanymi konkretnym zdarzeniem, a trzecia porusza problem mentalności.

\section{ZASOBY}

Potrzeba informacji w społeczeństwie wymusza na administracji publicznej stała gotowość do informowania i do tego celu wyspecjalizowano rzeczników, którzy stali się swoistym pomostem między swoim pracodawcą a społeczeństwem. Jednak nierzadko, ze względu na wagę problemu (zyski lub straty polityczne), zdarza się, że ich rolę przejmują sami szefowie, np. premier, wojewoda, prezydent miasta, burmistrz, wójt, dyrektorzy itp. W relacjach, bezpośrednio z miejsca zdarzenia, rolę informatora często przejmuje dowódca akcji ratowniczej lub wyznaczony przez niego przedstawiciel z formacji służb, inspekcji lub straży. Jednak mimo tych wyjątkowych sytuacji, informacja, szczególnie ta wrażliwa na spekulacje, powinna być pozyskiwana przez biuro prasowe lub samego rzecznika. Po pierwsze, taki komunikat dopracowany przez specjalistów trudniej zmanipulować. Po drugie, rzecznik i jego współpracownicy, ze względu na swoje doświadczenie i znajomość rynku, potrafią ocenić komu i jakie informacje przekazać. Często dochodzi do sytuacji, w której wypowiedź nieuprawnionych osób, także tych działających w dobrej woli, szkodzi instytucji, z której się wywodzą ${ }^{7}$. Obecnie nadal „większość instytucji w Polsce nie jest przygotowana do sytuacji kryzysowej z punktu zarządzania informacjami, zwykle w takich sytuacjach działania informacyjne mają charakter przypadkowy, w którym największą rolę odgrywa wyczucie sytuacji, a nie profesjonalizm w podejściu do dziennikarzy" (Konieczny, Wawrzynowicz, Mydlarska, 2011: 38).

Warto także wspomnieć, że ze względu na różną rangę problemu informacje powinny być rozpowszechniane adekwatnie do ich znaczenia i zasięgu. Wydaje się, że

5 Warto przypomnieć, że prawo prasowe w artykule 34 nakłada na środki masowego przekazu obowiązek publikacji „komunikatów przekazywanych przez organy administracji rządowej i samorządu terytorialnego w zakresie sytuacji kryzysowych, o których mowa w ustawie z dnia 26 kwietnia 2007 r. o zarządzaniu kryzysowym" (Ustawa, 1984). Tym samym nadawcy, szczególnie o zasięgu ogólnopolskim, stają się istotną częścią systemu bezpieczeństwa wewnętrznego.

${ }^{6}$ Obieg informacji bezsprzecznie wpływa na, jakże ważną w sytuacji kryzysowej, jakość informacji. „Potrzeby informacyjne kierowników zależą od ich usytuowania w hierarchii zarządzania. Kierownikom niższych szczebli, sprawującym kontrolę nad operacjami, potrzebne są częste, szczegółowe informacje - głównie ze źródeł wewnętrznych. Kierownikom średniego szczebla potrzebne są informacje zbiorcze, zarówno ze źródeł wewnętrznych, jak i zewnętrznych. Naczelnemu kierownictwu, zajmującemu się przede wszystkim planowaniem i kontrolą strategiczną, potrzebne są informacje w znacznym stopniu uogólnione, umożliwiające rozpoznanie ogólnych trendów i ocenę całkowitej efektywności” (Rogozińska-Mitrut, 2010: 97).

${ }^{7}$ Właśnie ta kwestia, tak zwanej niedźwiedziej przysługi, stała się główną przestrogą zawartą w podsumowaniu ćwiczeń w Dolsku, autorstwa Wielkopolskiego Wojewódzkiego Lekarza Weterynarii. 
obecnie ta zasada straciła posłuch, o czym świadczą mało istotne informacje kryzysowe pojawiające się w ogólnopolskich przekazach. W efekcie polityka informacyjna w Polsce realizowana przesadnie wywołuje niechęć społeczeństwa do takich treści, także tych pochodzących od dziennikarzy. Warto zaznaczyć, że obecnie redaktorzy tradycyjnych środków masowego przekazu (telewizji, radia, prasy drukowanej) również stanęli przed zagrożeniem marginalizacji. W społeczeństwie nasila się tendencja pozyskiwania wiedzy z jednego źródła - internetu. Przyczyna tego zjawiska sprowadza się głównie do natychmiastowego i bezkosztowego otrzymywania i przesyłania informacji oraz aktywizacji odbiorcy w doborze komunikatów. Dodatkowo zawodowi dziennikarze przegrywają ze specjalistami i pasjonatami, którzy publikują profesjonalne analizy na zasadzie wolontariatu. Przesyt informacji powoduje również niewielkie zainteresowanie mało atrakcyjnymi komunikatami administracji publicznej, o czym świadczy niewielka popularność stron internetowych konkretnych organów czy instytucji. Obecnie tak zobojętniałe społeczeństwo woli dowiadywać się o zdarzeniach za pośrednictwem środków masowego przekazu w komunikacie zmodyfikowanym (uatrakcyjnionym) przez redakcję, dziennikarza czy samego prezentera i często połączonym z politycznym absorbującym komentarzem. „Presja konkurencji sprawia, że na ogół sensacyjne, dramatyczne aspekty wydarzeń przeważają nad rzetelną analizą, bardziej liczy się forma przekazu, ze szkodą dla treści. Stąd brutalna pogoń za sensacją, by przekazać wiadomości interesujące dla odbiorców, walka o newsy, którą zwykle wygrywają szybsi i bezwzględniejsi, relacjonowanie i komentowanie wydarzeń bardziej z pozycji kreatora, niż obiektywnego obserwatora" (Kwiatkowski, 2012: 156).

Widać wyraźnie jakie znaczenie w takich przypadkach odgrywa pierwotny komunikat wysłany przez przedstawiciela administracji publicznej. Każda taka informacja powinna być spójna, pozbawiona emocji, bazować na prostych słowach, a w pośredni sposób mogłaby także budować pozytywny wizerunek władzy publicznej czy zaakcentować jej dobre relacje z dotkniętą kryzysem społecznością. Warto podkreślić, że nie mogą pojawiać się w ramach tej samej instytucji na różnych szczeblach odmienne, a nawet sprzeczne komunikaty. W ostatnim przypadku otwierają się przed dziennikarzami nieograniczone możliwości działania, co w dalszej perspektywie zawsze szkodzi wizerunkowi podmiotów odpowiedzialnych za bezpieczeństwo.

\section{ORGANIZACJA}

Środki masowego przekazu mają zdecydowanie większy wpływ na opinię publiczną niż sama administracja publiczna i tego faktu nie należy traktować jako zagrożenia, ale jako możliwość pozyskania doskonałego narzędzia do rozpowszechniania informacji. Trzeba jedynie zadbać o spójną politykę informacyjną, czyli udrożnić komunikację między najniższym a najwyższym szczeblem w danej instytucji oraz między podmiotami zainteresowanymi konkretną sytuacją kryzysowa, np. powiatową instytucją a starostwem powiatowym. Wystarczy prewencyjnie ustalić sposób komunikacji albo ostatecznie określić go już w czasie konkretnej sytuacji kryzysowej, aby utrudnić udaną manipulację medialną. 
W społeczeństwie informacyjnym praktycznie każde zdarzenie, także to o lokalnym zasięgu, może nabrać znaczenia ogólnokrajowego, stąd administracja publiczna na każdym szczeblu powinna podejść do sytuacji kryzysowej profesjonalnie: natychmiast reagować na zdarzenie oraz na bieżąco informować o swoich działaniach. Wydaje się, że jeszcze nie wszystkie podmioty odpowiedzialne za bezpieczeństwo, zdają sobie sprawę z wagi prowadzenia aktywnej polityki informacyjnej. Dzięki niej, w odróżnieniu do pasywnej (reagowania na informacje medialne), można kreować przekaz medialny i przede wszystkim kształtować relacje z odbiorcami. W głównej mierze chodzi o to, aby nie powstało złudzenie opieszałości czy, co gorsza, ignorowania problemu, a to wymaga racjonalnego gospodarowania informacją zewnętrzną i wewnętrzną. Obecnie, kiedy szybkość przekazu odgrywa zasadniczą rolę, wydaje się uzasadnione systematyczne zwiększanie autonomii dla niższych szczebli. Zdarza się, że ze względu na specyfikę rynku (nastawienie na zysk) i potrzebę uzyskania natychmiastowej informacji, dziennikarze z lokalnych ośrodków sięgają po opinię lub komentarz organów czy instytucji w najbliższym otoczeniu, a więc na szczeblu gminnym czy powiatowym, często pozbawionych etatowych rzeczników prasowych. „Na utrzymanie rzeczników prasowych, których jedynym obowiązkiem pracowniczym jest kontakt $\mathrm{z}$ prasą, mogą sobie pozwolić tylko największe, najzamożniejsze instytucje. Znacznie częściej rzecznictwo prasowe jest tylko dodatkowym zadaniem zapisanym w zakresie obowiązków pracowniczych (Ferenc-Szydełko, 2008: 95). Ostatecznie pierwsze komunikaty mogą wychodzić już od dowódców akcji ratowniczej, ale później obowiązek ten powinien przejąć wyższy szczebel z etatowym lub nieetatowym rzecznikiem prasowym. Należałoby także ustalić, który docelowo podmiot administracji publicznej zostanie jedynym źródłem informacji o zdarzeniu. Inaczej zwiększa się szansa wystapienia informacyjnego chaosu, ponieważ część obowiązków przypisanych ustawowo powiela się i w konsekwencji podmioty dublują się wzajemnie lub przerzucają obowiązki między sobą. W zależności od skali zagrożenia, komunikatów udzielać mogą służby, inspekcje i straże, zespoły zarządzania kryzysowego, centrum zarządzania kryzysowego i to na trzech różnych poziomach (wojewódzkim, powiatowym i gminnym) oraz organy (premier, wojewoda, prezydent miasta, burmistrz, wójt, sołtys). Warto podkreślić, że określenie (organizacja) polityki informacyjnej wymaga nie tyle współpracy wszystkich podmiotów zainteresowanych bezpieczeństwem, co chęci osiagnięcia kompromisu. Niestety różnorodne warunki, w których podejmuje się decyzje, uniemożliwiają odgórne ustalenie hierarchii w informowaniu, np. na mocy ustawy czy rozporządzenia.

Proponowana polityka informowania wydaje się w polskich warunkach możliwa do realizacji, o czym świadczą realia Mistrzostw Europy Euro 2012 w Poznaniu, kiedy określono właśnie sposób kontaktowania się z opinią publiczną a także wyznaczono drogę wymiany informacji między członkami Miejsko-Wojewódzkiego Sztabu Operacyjnego, który stał się ciałem wykonawczym do realizowania zadań w ramach zapewnienia bezpieczeństwa uczestnikom Euro 2012. W efekcie, przynajmniej na obszarze Wielkopolski, organizatorzy spełnili oczekiwania fanów piłki nożnej (szerzej: Magiera, 2013: 117-128). Trzeba podkreślić, że efekt ten udało się osiagnąć tylko dzięki wspólnemu stanowisku Wielkopolan wypracowanemu na szczeblu gminy, powiatu i województwa. 


\section{MENTALNOŚĆ}

W zarządzaniu kryzysowym, oprócz zasobów (sił i środków) oraz organizacji (regulacji, procedur itp.), wyjątkowe znaczenie należy przypisać mentalności. Bez umiejętnego zarządzania, odpowiedniego sposobu myślenia, pożądanych przekonań i twórczej postawy, nawet nieograniczone zasoby i duża autonomia w działaniu nie wystarczy do szybkiego i efektywnego usunięcia zagrożenia. W związku z tym polityka informacyjna musi zakładać istotną rolę czynnika ludzkiego. Po pierwsze, nie wszyscy sprawdzają się w sytuacji stresogennej (np. w roli nieetatowego rzecznika prasowego) i w natłoku zadań mogą komplikować i tak już wielopoziomowe i wielowątkowe działania antykryzysowe. Po drugie, indywidualne cechy osobiste wyraźnie wpływają na wybór i sposób prowadzenia polityki informacyjnej. W atmosferze nieufności czy konfliktów interpersonalnych autonomia w działaniu antykryzysowym pozostaje znacznie ograniczona lub nie występuje.

Zdarzają się spory, często długotrwałe, wynikające z pobudek osobistych, przypadkowych nieporozumień czy ambicjonalnych zapędów, które triumfują nad rzeczywistymi kompetencjami. „Na zachowania pracownika oddziałują nie tylko stosunki służbowe typu formalnego, ale w znacznie większym stopniu stosunki, a przede wszystkim jego uczestnictwo, w tzw. małych grupach nieformalnych" (Rogozińska-Mitrut, 2010: 17). Pojawiają się także rozbieżne interesy, o strukturze horyzontalnej i wertykalnej, ale należy traktować je jako zjawisko naturalne i często pożądane. Pierwsze, zazwyczaj dotyczą równorzędnych podmiotów (odpowiedników) z sąsiadujących, choć nie zawsze, gmin, powiatów czy województw. Drugie, obejmują jedną instytucję na różnych jej szczeblach. O ile rywalizację tych pierwszych można zrozumieć, o tyle konflikty w ramach tego samego podmiotu świadczą o jego anachronicznym zarządzaniu. Niechęć personalna ujawnia się także na styku władzy publicznej $\mathrm{z}$ podmiotami prywatnymi, co często widać $\mathrm{w}$ relacjach funkcjonariuszy publicznych z dziennikarzami. Dla niedoświadczonej osoby, pozbawionej wsparcia ze strony rzecznika prasowego i jego biura, te niejasne i nieformalne zależności, mogą wpłynąć i wpływają jednoznacznie na ocenę działalności administracji publicznej.

Należy mieć jednak nadzieję, że w każdej sytuacji kryzysowej bezpieczeństwo publiczne pozostaje na tyle zagrożone, że osobiste urazy tymczasowo pozostają zmarginalizowane. Przykładowo w czasie Mistrzostw Europy Euro 2012 w Wielkopolsce udało się przełamać dystans i wzajemny brak zaufania, co pozytywnie wpłynęło na późniejszą efektywność służb, inspekcji i straży oraz na samą ocenę organizacji tej międzynarodowej imprezy.

***

W czasie ćwiczeń w Dolsku, oprócz specjalistycznego przeszkolenia kadr starostw powiatowych i powiatowych lekarzy weterynarii, zademonstrowano także jakie trudności doświadczą uczestnicy szkolenia w kontaktach z przedstawicielami środków masowego przekazu. Obecnie, w zglobalizowanej i ciągle przyspieszającej rzeczywistości, niewiele osób ma czas na zainteresowanie się szczegółowymi analizami działalności antykryzysowej. Zdecydowana większość społeczeństwa skupia swoją uwagę na 
wyrywkowych informacjach pojawiających się w kilkuminutowych odsłonach w radiu czy telewizji i na ich podstawie ocenia efektywność działania administracji publicznej. Zatem należy zwracać szczególną uwagę na sposób informowania, a dokładniej umiejętnie przekazywać opracowane komunikaty, by utrudnić ewentualną manipulację. Obecnie sprawdza się metoda kontroli informacji przez uprzedzanie środków masowego przekazu i zaskakiwanie ich nowymi danymi. Przejęcie inicjatywy ułatwiają sprzężone masowe komunikaty nadawane przez ustanowionych pełnomocników ad hoc. W skrajnych przypadkach, potwierdzonych w rzeczywistości, okazuje się, że nie tyle samo reagowanie kryzysowe ma znaczenie, co przekaz mówiący o nim.

Decydenci, poczynając od centralnej administracji rządowej, przez terenową, a kończąc na gminnej administracji samorządowej, oczekują szybkiego rozwiązania sytuacji kryzysowej. Sukces w tym przypadku zwiększa popularność dowolnego polityka (lidera) bez względu na polityczne korzenie. Przychylny przekaz zawsze będzie pożądany, ponieważ, „mediatyzacja kultury, będąca konsekwencją rosnącego znaczenia mediów, zmienia pojęcia sukcesu i wyjątkowości. O ich osiągnięciu decyduje bowiem obecność w mediach, nie zasługi osobiste" (Piontek, 2011: 95). Zatem już od najniższych szczebli w każdej instytucji neutralizacja zagrożenia powinna stać się priorytetem w działaniu. Na marginesie można wspomnieć, że z punktu widzenia politycznego wyjątkowe korzyści można osiagnąć przy katastrofie naturalnej. Zawsze sprzyjają one zwiększeniu poparcia społecznego, ponieważ źródłem ich wystąpienia pozostają żywioły i trudno doszukać się zaniedbań (błędów czynnika ludzkiego). Potwierdzeniem tej tezy jest wyjątkowo pozytywny wizerunek państwowej i ochotniczej straży pożarnej. Jednak w polskiej rzeczywistości usatysfakcjonowanie społeczeństwa staje się niemożliwe bez prawidłowej polityki informacyjnej, a tej brakuje. Idealna sytuacja sprowadzałaby się do eliminacji szumu komunikacyjnego, czyli sprowadzenia środków masowego przekazu do biernego nośnika informacji ${ }^{8}$ oraz wyposażenia kompetentnej emocjonalnie $^{9}$ osoby informującej o zdarzeniu w pełne i systematycznie aktualizowane informacje. Spełnienie potrzeby kompleksowego minimalizowania ryzyk w polskim społeczeństwie dokona się nie poprzez materialną i organizacyjną modyfikację administracji publicznej, ale głównie wskutek szkoleń i pracy nad naszą mentalnością.

\section{Bibliografia}

Cieślarczyk M. (2009), Tożsamość stużb reagowania kryzysowego w świetle socjologicznego modelu kultury bezpieczeństwa, w: Tożsamość społeczna grup dyspozycyjnych, (red.) J. Maciejewski, W. Nowosielski, Wrocław.

8 Współpraca ze środkami masowego przekazu powinna opierać się na partnerstwie. Nie można ulegać ,pokusie zdobywania przychylności mediów w sposób najprostszy, starając się je kontrolować, podporządkować, a przynajmniej sprawić, by nie były nazbyt krytyczne w ocenie organizacji zarządzania kryzysowego oraz służb biorących udział w akcji” (Kwiatkowski, 2012: 159).

9 „Dobry i skuteczny rzecznik to osoba komunikatywna, która posiada łatwość wypowiadania się, a przy tym nie jest ekspansywna i potrafi kontrolować swoją ekspresję emocjonalną. Jego cechy osobowościowe określają pierwsze wrażenie wywierane przezeń na słuchaczach i rozmówcach, a w konsekwencji limitują komunikatywność przekazu" (Pietrzak, Hałaj, 2003: 12). 
Dobosz I. (2008), Prawo i etyka w zawodzie dziennikarza, Warszawa.

Dylus A. (2007), Stużba (publiczna): cnota zapomniana, w: Etos urzędnika, (red.) D. Bąk, Warszawa. Ferenc-Szydełko E. (2008), Prawo prasowe: komentarz, Warszawa.

Konieczny J., Wawrzynowicz H., Mydlarska J. (2011), Psychologia bezpieczeństwa, Poznań.

Kwiatkowski S. (2012), Zarzadzanie bezpieczeństwem w sytuacjach kryzysowych, Pułtusk.

Magiera M. (2013), Kultura bezpieczeństwa wimprezach masowych w Wielkopolsce. Analiza dziatań Miejsko-Wojewódzkiego Sztabu Operacyjnego Euro 2012 w Poznaniu, „Przegląd Politologiczny", nr 2.

Pietrzak H., Hałaj J. (2003), Rzecznik prasowy, Rzeszów.

Piontek D. (2011), Komunikowanie polityczne i kultura popularna. Tabloidyzacja informacji o polityce, Poznań.

Rogozińska-Mitrut J. (2010), Podstawy zarzadzania kryzysowego, Warszawa.

Schulz W. (2006), Komunikacja polityczna, Kraków.

Sienkiewicz-Małyjurek K., Krynojewski F. (2010), Zarzadzanie kryzysowe w administracji publicznej, Warszawa.

Sobczak J. (2010), U podstaw doktrynalnych liberalnej koncepcji wolności prasy, w: Czy istnieje IV władza? Wolność prasy w teorii i praktyce, (red.) T. Gardocka, J. Sobczak, Torun.

Ustawa Prawo prasowe (1984), Dz. U., nr 5, poz. 24, z późn. zm.

\title{
STRESZCZENIE
}

Administracja publiczna, ze względu na swoją istotę (służbę), musi spełniać oczekiwania społeczne, stąd oprócz modernizacji zasobów, reorganizacji należy także modyfikować jej mentalność. Inaczej bez systematycznego dostosowywania się do jakże dynamicznej rzeczywistości zawiedzie i przeistoczy się w dysfunkcjonalną strukturę. W społeczeństwie ryzyka, w społeczeństwie informacyjnym, a takim niewątpliwie jesteśmy, newralgicznym elementem, szczególnie w sytuacjach kryzysowych, stała się polityka informacyjna. Warto zatem scharakteryzować jej istotę $\mathrm{i}$ wpływ na otoczenie, by następnie podmiotom zainteresowanym bezpieczeństwem przedstawić dostosowawcze rekomendacje o kluczowym znaczeniu. Należy pamiętać, że zdecydowana większość społeczeństwa ocenia rzeczywistość na podstawie wyrywkowych informacji z mass mediów, niż na szczegółowej analizie działalności administracji publicznej.

\section{INFORMATION POLICY OF PUBLIC ADMINISTRATION IN CRISIS SITUATIONS}

\begin{abstract}
Public administration, in view of its essence, must satisfy social expectations. In addition, to modernization resources, reorganization, should also modify its mentality. Otherwise without systematic adaptation to a dynamic reality it fails and will transform into the dysfunctional structure. In the risk society, the information society, and this undoubtedly we are, the information policy, especially in crisis situations, has become the boiling issue. It is useful to characterize its essence and impact on the environment, would introduce entities those who are interested in security adjustment recommendations on key issues. It should be remembered that the vast majority of society is assessed on the bases of random information from the mass media rather than on detailed analysis of the public administration.
\end{abstract}


